\title{
Effect of Different Fertility Levels and Organic Nutrient Sources on Growth and Yield of Wheat (Triticum aestivum L. Emend. Fiori \& Paol)
}

\author{
Meenakshi Meena* and Mamta Meena \\ Faculty of Agriculture, Vivekananda Global University, Jaipur-302012, India \\ *Corresponding author
}

\section{A B S T R A C T}

\section{Keywords}

RDF, PSB,

Azotobacter,

Vermicompost,

Fertility levels,

Growth and yield attributes

Article Info

Accepted:

08 January 2020

Available Online:

10 February 2020
The experiment was conducted in split plot design with fifteen treatments combinations with three replications during rabi season 2018-19. The experiment consisted of three levels of fertility as main factor and five levels of organic sources assigning to sub-plots by replicating thrice. Three fertility levels were $75 \%$ recommended dose of fertilizers (RDF), $100 \%$ RDF (120:60:60 NPK) and 125\% RDF. The five levels of organic sources were control, vermicompost @ $2.5 \mathrm{t} \mathrm{ha}^{-1}$, vermicompost @ $2.5 \mathrm{t} \mathrm{ha}^{-1}+$ Azotobacter + PSB, FYM (farmyard manures)@5 t ha ${ }^{-1}$ and FYM @ $5 \mathrm{t}$ $\mathrm{ha}^{-1}+$ Azotobacter + PSB. Among fertility levels, the application of $100 \%$ RDF being at par with $125 \%$ RDF recorded maximum growth and yield attributes, grain (40.19 and $41.88 \mathrm{q} \mathrm{ha}^{-1}$, respectively) and straw (58.27 and $60.72 \mathrm{q} \mathrm{ha}^{-1}$, respectively). Similarly, the application of FYM @ $5 \mathrm{t} \mathrm{ha}^{-1}$ being at par with vermicomposting @ $2.5 \mathrm{t} \mathrm{ha}^{-1}$ significantly increased growth parameters, yield and yield parameters of wheat.

\section{Introduction}

Wheat (Triticum aestivum L.) is the world's leading cereal crop cultivated over an area of about 651 million tons making it the third most-produced cereal after maize and rice. It plays an important role in food and nutritional security as it is an excellent health building staple food consumed by nearly 65 per cent of the population in various forms and thus, emerged as the backbone of India's food security. It is most important staple food of about two billion people (36\% of the World population). About $55 \%$ of the world population depends on wheat for intake of about $20 \%$ of food calories therefore, known as 'king of cereals. Wheat grains are comparatively better source of protein consumed in India. About 10-12\% protein requirement is met by wheat. Maneuvering the application of different fertilizers could increase the productivity of the wheat crop and the protein content. On account of continuing world energy crisis and spiraling 
price of chemical fertilizer, the use of organic manure as a renewable source of plant nutrients is assuming importance. In this endeavor proper blend of organic manure and inorganic fertilizer is important not only for increasing yield but also for sustaining soil health (Kumar et al., 2013).

Organic manure enhanced soil organic carbon quality and quantity by an increased accumulation of various classes of organic compounds. Vermicompost technology promoted by earthworms, FYM, and biofertilizers are the strong health promoter, improves soil organic carbon and biological properties, nutrient recycling and maintains the soil fertility and productivity. Addition of these manures to the soil system also improves the physical conditions including soil structure, porosity, reduces compaction \& crusting and overall increases water holding capacity of the soil (Singh et al., 2010). Integrated nutrient management involves the integrated use of mineral fertilizers together with organic manure in suitable combination compliments and each other to optimize input use and maximize production and sustain the same without impairing the crop quality or soil health. The integration of nutrient supplying sources is a flexible approach to minimize the use of chemical sources of nutrient along with maximization of their efficiency and farmer's economics.

\section{Materials and Methods}

A field experiment was conducted during rabi 2018-18 at the Agricultural Research Farm, Vivekanand Global University, Jaipur, Rajasthan which is situated at a latitude of $26^{\circ}$ $81^{\prime} \mathrm{N}$, longitude $75^{\circ} 889^{\prime} \mathrm{E}$ and altitude of 260 meters above mean sea level. The field experiment was laid out with three fertility levels randomly allocated to the main plots of split plot design and five levels of organic sources assigning to sub-plots by replicating thrice. Three fertility levels were $75 \%$ recommended dose of fertilizers (RDF), 100\% RDF (120:60:60 NPK) and 125\% RDF. The five levels of organic sources were control, vermicompost @ $2.5 \quad \mathrm{t} \quad \mathrm{ha}^{-1}$, vermicompost @ $2.5 \mathrm{t} \mathrm{ha}^{-1}+$ Azotobacter + PSB, FYM (farmyard manures) @ $5 \mathrm{t} \mathrm{ha}^{-1}$ and FYM@5 t ha ${ }^{-1}+$ Azotobacter + PSB. The treatments using split plot design with fifteen treatments combinations with three replications.

\section{Results and Discussion}

\section{Effect of fertility levels and organic sources on growth}

The plant height of wheat was increased with increasing days from sowing to harvest and the maximum increment was noticed between 60 to 90 DAS (days after sowing), after that increased but at decreased rate by all the nutrient management practices. Among different fertility levels, application of $100 \%$ RDF (120:60:60) significantly promoted plant height and dry matter accumulation (Table 1.1) compared to the $75 \% \mathrm{RDF}$ at $30,60,90$ DAS and at harvest stage. In contrast, the treatment of $125 \%$ RDF retained statistically comparable plant height with the $100 \%$ RDF at all the crop growth stages. In contrast, the treatment of $125 \%$ RDF retained statistically comparable plant height with the $100 \%$ RDF at all the crop growth stages.

Among organic sources, application of FYM (a) $5 \mathrm{t} \mathrm{ha}^{-1}+$ Azotobacter + PSB $\left(\mathrm{O}_{5}\right)$ significantly promoted plant height as compared to remaining treatment combinations at 30, 60, 90 DAS at harvest stage. Although, application of vermicompost @ $2.5 \mathrm{t} \mathrm{ha}^{-1}+$ Azotobacter + PSB was statistically at par in term of plant height with the treatment $\mathrm{O}_{5}$ at all the crop growth stages. Although, this treatment was statistically nonsignificant with application of vermicompost @ $2.5 \mathrm{t} \mathrm{ha}^{-1}+$ Azotobacter + PSB in terms of dry matter production at all the stages. 
Table.1 Plant height and dry matter accumulation of wheat as influenced by different fertility levels and organic sources

\begin{tabular}{|c|c|c|c|c|c|c|c|c|}
\hline \multirow[t]{2}{*}{ Treatment } & \multicolumn{4}{|c|}{ Plant height (cm) } & \multicolumn{4}{|c|}{ Dry matter accumulation (g plant ${ }^{-1}$ ) } \\
\hline & $\begin{array}{c}30 \\
\text { DAS }\end{array}$ & $\begin{array}{c}60 \\
\text { DAS }\end{array}$ & $\begin{array}{c}90 \\
\text { DAS }\end{array}$ & $\begin{array}{c}\text { At } \\
\text { harvest }\end{array}$ & $\begin{array}{c}30 \\
\text { DAS }\end{array}$ & $\begin{array}{c}60 \\
\text { DAS }\end{array}$ & $\begin{array}{c}90 \\
\text { DAS }\end{array}$ & $\begin{array}{c}\text { At } \\
\text { harvest }\end{array}$ \\
\hline \multicolumn{9}{|l|}{ Fertility levels } \\
\hline$F_{1}-75 \%$ RDF & 17.80 & 42.01 & 70.97 & 87.67 & 0.86 & 3.09 & 10.68 & 13.52 \\
\hline $\mathrm{F}_{2}-100 \% \mathrm{RDF}$ & 19.15 & 45.16 & 76.29 & 94.24 & 0.93 & 3.32 & 11.48 & 14.53 \\
\hline$F_{3}-125 \% \mathrm{RDF}$ & 19.28 & 45.29 & 76.51 & 94.51 & 0.94 & 3.33 & 11.51 & 14.58 \\
\hline SEm \pm & 0.371 & 0.818 & 1.301 & 1.688 & 0.019 & 0.059 & 0.216 & 0.264 \\
\hline CD at $5 \%$ & 1.21 & 2.67 & 4.24 & 5.51 & 0.06 & 0.19 & 0.70 & 0.86 \\
\hline $\mathrm{CV}(\%)$ & 7.67 & 7.18 & 6.76 & 7.10 & 7.88 & 7.02 & 7.46 & 7.20 \\
\hline \multicolumn{9}{|l|}{ Organic sources } \\
\hline $\mathbf{O}_{1}-$ Control & 17.01 & 39.92 & 67.44 & 83.30 & 0.83 & 2.94 & 10.14 & 12.85 \\
\hline $\mathrm{O}_{2}$-Vermicompost @ $2.5 \mathrm{t} \mathrm{ha}^{-1}$ & 18.47 & 43.49 & 73.46 & 90.74 & 0.90 & 3.20 & 11.05 & 13.99 \\
\hline $\begin{array}{l}\mathrm{O}_{3}-\text { Vermicompost @ } 2.5 \mathrm{tha}^{-1}+\text { Azotobacter } \\
+ \text { PSB }\end{array}$ & 19.92 & 47.03 & 79.45 & 98.15 & 0.97 & 3.46 & 11.95 & 15.14 \\
\hline $\mathrm{O}_{4}-\mathrm{FYM} @ 5 \mathrm{tha}^{-1}$ & 18.32 & 43.12 & 72.85 & 89.99 & 0.89 & 3.17 & 10.96 & 13.88 \\
\hline $\mathrm{O}_{5}-\mathrm{FYM} @ 5 \mathrm{t} \mathrm{ha}^{-1}+$ Azotobacter + PSB & 20.00 & 47.21 & 79.75 & 98.52 & 0.97 & 3.47 & 12.00 & 15.19 \\
\hline SEm \pm & 0.403 & 1.079 & 1.786 & 2.208 & 0.020 & 0.078 & 0.271 & 0.342 \\
\hline CD at $5 \%$ & 1.19 & 3.18 & 5.27 & 6.51 & 0.06 & 0.23 & 0.80 & 1.01 \\
\hline CV $(\%)$ & 6.45 & 7.33 & 7.18 & 7.19 & 6.44 & 7.17 & 7.25 & 7.23 \\
\hline
\end{tabular}


Table.2 Yield attributes and yield of wheat as influenced by different fertility levels and organic sources.

\begin{tabular}{|c|c|c|c|c|c|c|}
\hline Treatment & Tillers $\mathbf{m}^{-2}$ & $\begin{array}{l}\text { Spike length } \\
(\mathrm{cm})\end{array}$ & $\begin{array}{l}\text { Grains } \\
\text { spike }^{-1}\end{array}$ & $\begin{array}{c}\text { 1000- } \\
\text { grains } \\
\text { weight (g) }\end{array}$ & $\begin{array}{l}\text { Grain yield } \\
\qquad\left(\mathbf{q ~ h a} \mathbf{~}^{-1}\right)\end{array}$ & $\begin{array}{l}\text { Straw yield } \\
\qquad\left(\mathbf{q} \mathbf{h a}^{-1}\right)\end{array}$ \\
\hline \multicolumn{7}{|l|}{ Fertility levels } \\
\hline $\mathrm{F}_{1}-75 \% \mathrm{RDF}$ & 304 & 9.31 & 48.48 & 41.13 & 36.15 & 52.41 \\
\hline $\mathrm{F}_{2}-100 \% \mathrm{RDF}$ & 338 & 10.18 & 53.05 & 42.87 & 40.19 & 58.27 \\
\hline $\mathrm{F}_{3}-125 \% \mathrm{RDF}$ & 353 & 10.53 & 54.84 & 42.95 & 41.88 & 60.72 \\
\hline SEm \pm & 6.5 & 0.19 & 1.071 & 0.484 & 0.765 & 1.094 \\
\hline CD at $5 \%$ & 21 & 0.62 & 3.49 & 1.58 & 2.49 & 3.57 \\
\hline CV (\%) & 7.57 & 7.40 & 7.95 & 4.43 & 7.52 & 7.41 \\
\hline \multicolumn{7}{|l|}{ Organic sources } \\
\hline $\mathrm{O}_{2}$-Vermicompost @ $2.5 \mathrm{t} \mathrm{ha}^{-1}$ & 327 & 9.63 & 50.14 & 41.56 & 38.82 & 56.27 \\
\hline $\begin{array}{l}\mathrm{O}_{3}-\text { Vermicompost @ } 2.5 \mathrm{t} \mathrm{ha}^{-1}+ \\
\text { Azotobacter + PSB }\end{array}$ & 354 & 10.66 & 55.55 & 43.45 & 41.97 & 60.84 \\
\hline $\mathbf{O}_{4}-$ FYM @ $5 \mathbf{t h a}^{-1}$ & 324 & 9.90 & 51.59 & 42.69 & 38.49 & 55.80 \\
\hline $\begin{array}{l}\mathrm{O}_{5}-\mathrm{FYM} @ 5 \mathrm{t} \mathrm{ha}^{-1}+\text { Azotobacter }+ \\
\text { PSB }\end{array}$ & 355 & 10.71 & 55.77 & 43.63 & 42.13 & 61.07 \\
\hline SEm \pm & 8.15 & 0.195 & 1.053 & 0.686 & 0.959 & 1.371 \\
\hline CD at $5 \%$ & 24 & 0.58 & 3.11 & 2.02 & 2.83 & 4.05 \\
\hline CV $(\%)$ & 7.37 & 5.85 & 7.15 & 4.86 & 7.30 & 7.20 \\
\hline
\end{tabular}


The plant height and dry matter accumulation continuously increased with the advancement of the age of crop up to the maturity. The maximum increment in plant height and dry matter accumulation was noticed between 60 to 90 DAS after that it was increased but at decreasing rate across the fertility levels and organic sources. Because during this stage, the available nutrients were utilized for the lateral growth of the plants. Among the fertility levels, the application of $100 \%$ RDF recorded significantly greater plant height and dry matter accumulation during the entire crop growth stages over the $75 \%$ RDF. Although, it was statistically at par with the $125 \%$ RDF at the same growth stages. The use of high amount of organic manure would have facilitated better aeration, adequate drainage, improved soil biological activities and created a favorable soil environment for deeper proliferation of roots and higher nutrient extraction from soil, caused more vigorous plant growth. The increased plant height and dry matter production might be due to the involvement of nutrients in cell wall development and cell differentiation which resulted elongation of shoot and root in plants. Similar results were obtained by Ahmed et al., (2013) who had reported that an appropriate supply of nutrients through organic and inorganic sources increased the growth attributes of wheat. The results are in agreement with the findings of Kaur et al., (2018) and Mohan et al., (2018).

\section{Effect of fertility levels and organic sources on yield}

The data concerning to yield attributing characters of wheat presented in Table 1.2 revealed that different fertility levels significantly influenced the tiller $\mathrm{m}^{-2}$, spike length $(\mathrm{cm})$, grains spike ${ }^{-1}$ and 1000-grain weight $(\mathrm{g})$. Data revealed that the application of $100 \%$ RDF recorded significantly a greater number of tiller $\mathrm{m}^{-2}$ (338) spike length (10.53 $\mathrm{cm})$, grains spike $^{-1}$ (54.84) and 1000-grain weight $(42.95 \mathrm{~g})$ compared to the fertility levels. Even though, 125\% RDF had statistically non-significant with $100 \%$ RDF in terms of all of these yield parameters. Similarly, the lowest value of all the yield attributing features was observed from application of $75 \%$ RDF. The highest grain and straw yield was recorded with combined application of $125 \%$ RDF (41.88 q ha ${ }^{-1}$ ) which was statistically at par with $125 \%$ RDF (40.19 $\mathrm{q} \mathrm{ha}^{-1}$ ). On the opposite, the 75\% RDF plot produced significantly lowest grain yield of wheat. The magnitude of increase in grain yield was 11.18 and $13.91 \%$ in $100 \%$ RDF and $125 \%$ RDF over $75 \%$ RDF, respectively. It is obvious from the Table 1.2 that application of $100 \%$ RDF had significantly advanced straw yield over the $75 \%$ RDF and remained statistically at par with the $125 \%$ RDF. The application of both $100 \%$ RDF and $125 \%$ were significantly superior to the $75 \%$ RDF.

In this regard, the application of FYM @ $5 \mathrm{t}$ $\mathrm{ha}^{-1}+$ Azotobacter + PSB produced significantly higher number of all the yield attributing traits. In contrast, the production of tillers, spike length and grains spike $^{-1}$ in vermicompost @ $2.5 \mathrm{t} \mathrm{ha}^{-1}+$ Azotobacter + PSB were non- significant with the $\mathrm{O}_{5}$. Similarly, the application of FYM @ $5 \mathrm{t} \mathrm{ha}^{-1}$ + Azotobacter + PSB retained statistically comparable test weight with the vermicompost@2.5 t ha ${ }^{-1}+$ Azotobacter + PSB, FYM @ $5 \mathrm{t} \mathrm{ha}^{-1}$ and vermicompost @ $2.5 \mathrm{t} \mathrm{ha}^{-1}$. Significantly lowest value of all the yield attributing characters was noticed in absolute control plot where nothing was applied.

Among organic sources, the highest seed yield $\left(42.13 \mathrm{q} \mathrm{ha}^{-1}\right)$ and straw yield $(61.07 \mathrm{q}$ $\mathrm{ha}^{-1}$ ) was recorded with combined application of FYM @ $5 \mathrm{t} \mathrm{ha}^{-1}+$ Azotobacter + PSB. This was significantly superior to remaining 
treatments but statistically at par with the vermicompost@2.5 t ha ${ }^{-1}+$ Azotobacter + PSB. Both of these treatments had significantly superior grain yield over the remaining combinations. The magnitude of increase in grain yield was 18.21 and $17.76 \%$ in FYM @ $5 \mathrm{t} \mathrm{ha}^{-1}+$ Azotobacter + PSB and vermicompost@2.5 t ha ${ }^{-1}+$ Azotobacter + PSB over control, respectively.

The data on yield attributes showed that the plants received $100 \%$ RDF recorded significantly a greater number of tillers (338 $\left.\mathrm{m}^{-2}\right)$, spike length $(10.18 \mathrm{~cm})$, grains spike ${ }^{-1}$ (53.05) and 1000-grain weight $(42.87 \mathrm{~g})$ compared to the remaining treatment combinations. Even though, 125\% RDF was statistically non-significant with $100 \%$ RDF in terms of the entire yield attributes. This might be due to the fact that application of vermicompost/FYM + azotobacter + PSB with inorganic fertilizer judiciously increased the nitrogen supply which resulted in the increased conversion of carbohydrates in to proteins which in turn are elaborated in to protoplasm. The improvement in growth attributing parameters directly supports the development of yield attributing characters. Therefore, the better assimilation of photosynthate and their partitioning into developing spike might have taken place that improved yield attributing characters like tillers $\mathrm{m}^{-2}$, spike length, grains spike ${ }^{-1}$ and 1000-grains weight. Similarly, Ahmad et al., (2013); Patel et al., (2017) and Singh et al., (2019) also reported the improved yield attributes of wheat crop with integration of synthetic fertilizers and organic manures.

\section{References}

Kumar, M., Bauddh, K., Kumar, S., Sainger, M., Sainger. P. A. and Singh, R. P. 2013. Increase in growth, productivity and nutritional status of wheat (Triticum aestivum L. cv. WH-711) and enrichment in soil fertility applied with organic matrix entrapped urea. Journal of Environmental Biology, 34: 1-9.

Singh, G., Singh, O. P., Singh, S. and Prasad, K. 2010. Weed management in late sown wheat (Triticum aestivum) after rice (Oryza sativa) in rice-wheat system in rainfed lowland. Indian Journal of Agronomy, 55(2): 83-88.

Ahmad, M., Afzal, M., Ahmad, M., Ahmad, A.U.H. and Azeem, M.I. 2013. Role of organic and inorganic nutrient sources in improving wheat crop production. Cercetări Agronomice în Moldova, XLVI(153): 15-21.

Kaur, R., Kumar, S., Kaur, R. and Kaur, J. 2018. Effect of integrated nutrient management on growth and yield of wheat (Triticum aestivum L.) under irrigated conditions. International Journal of Chemical Studies, 6(4): 1800-1803.

Mohan, B, Kumar, P. and Yadav, R.A. 2018. Effect of integrated nutrient management on yield attributes and yield of wheat (Triticum aestivum L.). Journal of Pharmacognosy and Phytochemistry, 7(1): 1545-1547.

Patel, T.G., Khushvadan, C.P. and Patel, V.N. 2017. Effect of integrated nutrient management on yield attributes and yield of wheat (Triticum aestivum L.). International Journal of Chemical Studies, 5: 1366-1369.

Singh, G., Kumar, S., Singh, G. and Singh, N. 2019. Effect of integrated nutrient management on nutrient uptake and grain yield of wheat (Triticum aestivum L.) under irrigated conditions. Journal of Pharmacognosy and Phytochemistry, 8 (1): 1077-1080. 
How to cite this article:

Meenakshi Meena and Mamta Meena. 2020. Effect of Different Fertility Levels and Organic Nutrient Sources on Growth and Yield of Wheat (Triticum aestivum L. Emend. Fiori \& Paol). Int.J.Curr.Microbiol.App.Sci. 9(02): 1624-1630. doi: https://doi.org/10.20546/ijcmas.2020.902.186 